\title{
CDS Primleri ile Portföy Yatırımları Arasındaki lisscinin Değerlendirilmesi: Türkiye Örneği
}

Güven SEViL' - Tutku ÜNKARACALAR²

Makale Gönderim Tarihi: 03.12.2019

Makale Kabul Tarihi: 16.03.2020

\section{Öz}

Bu çalıșmada, Türkiye'ye ilișkin CDS primleri ile porfföy yatııımları arasındaki ilișki 2010-2018 yılları arasındaki üçer aylık veriler kullanılarak zaman serisi analizi ile incelenmiștir. Bu amaç doğrultusunda ilk olarak çalıșmada kullanılan serilerin arasında uzun dönemli ilișkinin olup olmadığının tespit edilmesi amacıyla Johansen Eșbütünleșme Testi uygulanmıștır. Değișkenler arasında koentegrasyon olduğu tespit edildiği için kullanılan Tam Düzeltilmiș En Küçük Kareler Yöntemi (FMOLS) sonucunda elde edilen bulgular, porfföy yatıımları ile CDS primleri arasında negatif ilișki olduğunu göstermektedir. Ayrıca değișkenler arasında kısa dönem ilișkinin tespiti ise Granger Nedensellik Testi ile incelenmiș ve porfföy yatııımlarının CDS primleri üzerinde kısa dönemde bir etkisinin olduğu tespit edilmiștir.

Anahtar Kelimeler: CDS primleri, Porfföy Yatırımları, Tam Düzeltilmiș En Küçük Kareler Yöntemi, Granger Nedensellik Testi

Jel Siniflaması: C10, C32, G10, G1 1

Prof. Dr., Anadolu Üniversitesi, İktisadi ve İdari Programlar Anabilim Dalı, gsevil@anadolu. edu.tr, Orcid ID: 0000-0001-7592-3799

2 (Sorumlu Yazar) Arș. Gör., Kırklareli Üniversitesi, Uygulamalı Bilimler Yüksekokulu, Muhasebe ve Finansal Yönetim Anabilim Dalı, ututku@klu.edu.tr, Orcid ID: 0000-0002-6584-868 1 


\section{An Assessment of The Relationship Between CDS Spreads And Portfolio Investments: Turkey Case}

\section{Abstract}

In this study, the relationship between CDS spreads for Turkey and porffolio investments is investigated through time series analysis, using the quarterly data from 2010 to 2018 . or this purpose, firstly, Johansen Cointegration Test was performed to determine if there is a long run relationship between the series used in the study. As there is a cointegration of the variable, the findings from Fully Modified Ordinary Least Squares show that there is a negative relationship between porffolio investments and CDS spreads. Furthermore, the short run relationship between the variables was investigated using Granger Causality Test and it was determined that porffolio investments have an effect upon CDS spreads in the short run.

Keywords: CDS Spreads, Porffolio Investments, Fully Modified Ordinary Least Squares, Granger Causality Test

Jel Clasifications: C10, C32, G10, G1 1

\section{Giriș}

JP Morgan Chase tarafından 1995 yılında geliștirilen ve 1997 yılında ihraç edilen Kredi Temerrüt Swapı (Credit Default Swap; CDS) en basit tanımıyla, kredi riskinin taraflar arasında transferini sağlamak amacıyla satın alınan bir finansal sigorta sözleșmesiyken; genel anlamıyla, borcun geri ödenmemesi riskinden korunmak amacıyla alacaklının üçüncü bir tarafa belirli bir prim karșilığında alacağını garanti etmek için yaptırdığı kredi türev enstrümanıdır.

CDS alıcısı, satan tarafa, CDS'in vadesi boyunca ya da bir kredi durumu olușuncaya kadar periyodik ödemeler yapmayı kabul etmektedir. Anaparayı temsil eden tutarın yüzdesi olarak ödenen primler, CDS primi olarak adlandırılmaktadır. Kredi temerrüt swaplarının primlerindeki bir artıș, temerrüde düsșme olasılığının arttığına ve dolayısıyla borçlanma maliyetlerinin yükseldiğine ișaret etmekte ve piyasalarda endișelerin artmasına yol açmaktadır. Ayrıca makroekonomik görünüme ilișkin ekonomik belirsizliğin artmasına yol açarak, finansal stres altındaki ülkeye olan yatırımları negatif yönde etkileyebilmektedir (Kılcı, 2019, s. 76). 
CDS primini ülkenin veya firmanın iflas etme olasılığı belirler. Yani CDS satanlar perspektifinden ülkenin veya firmanın iflas etme riski ile CDS primleri arasında doğru orantı mevcuttur. Böylece iflas etme riski arttıkça, CDS satanlar daha yüksek ücret talep ederler. CDS'lerin genel ișleyiși așağıdaki șekilde gösterilmiștir (Weistroffer, 2009, s. 4).

\section{Șekil 1. CDS İșleyiși}

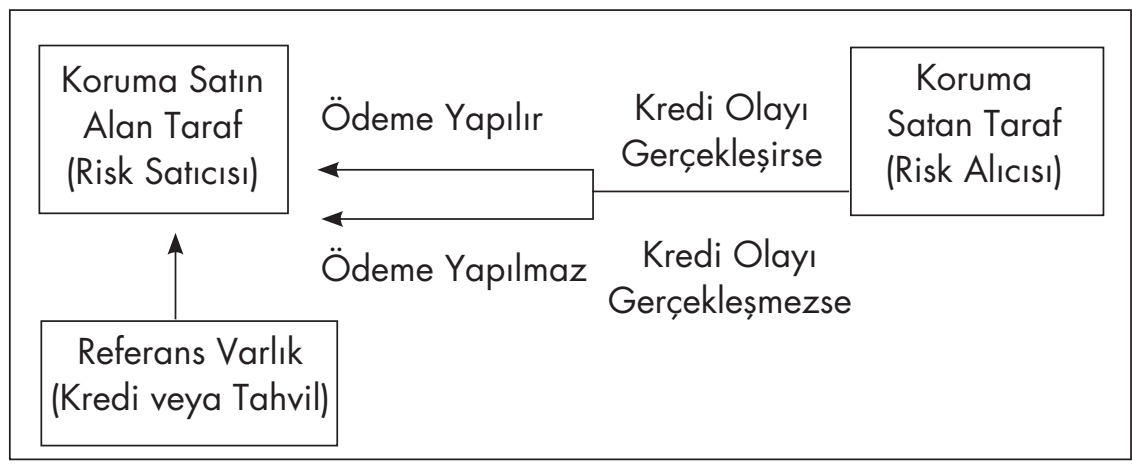

Kaynak: Choudhry, 2006, s. 2

CDS'ler hem șirket, banka gibi kurumlar hem de ülkeler tarafından çıkartılabilmektedir. Ülkelere ait CDS'ler o ülkeye ait devlet tahvillerini veya eurobondları esas alırken; șirketlere ait olan CDS'ler ise șirketlerin bonoları, kredileri veya tahvilleri referans alınarak çıkartılmaktadır (Görmüș ve Aksoylu, 2017, s. 204).

CDS'ler genellikle riskten korunma, spekülasyon veya arbitraj amacıyla kullanılmaktadır. Bașta bankalar, kredi temerrüt swapı satın alarak biriken riskin belirli bir kısmını üçüncü bir tarafa devretmektedir. Böylece hem banka müșterisini kaybetmekten ve yoğunlașma riskinden kurtulmuș olur hem de șirket yeni bir banka arayıșına girmek zorunda kalmamıș olur. Bankanın CDS'e bașvurmasının diğer bir sebebi de riskten portföy farklılaștırılması, menkul kıymetleștirilmesi ya da kredi satıșı gibi yollarla da korunabilirken; bu yöntemlerle çok daha fazla maliyete katlanmak zorunda kaldığı için CDS sözleșmesi ile daha az maliyetle kendini güvence altına almak istemesidir.

Kredi temerrüt swap sözleșmeleri temel olarak iki gruba ayrılmaktadırlar. Birincisi, bir tek referans borçlusu olan "Basit Kredi Temerrüt Swapı"dır, bu çeșit swap aynı zamanda "Tek İsimli Kredi Temerrüt Swapı" olarak da bilinmektedir. Bir diğeri ise standardize edilmiș koșullara sahip tek isimli, diğer bir ifade ile bir tek referans borçlusu olan kredi 
temerrüt swaplarından olușan bir sepettir. Bu çeșit swaplar, "Kredi Temerrüt Swapı Endeksi" olarak da adlandırılmaktadır (Anson, Fabozzi, Choudhry ve Chen, 2004, s. 48).

Kredi temerrüt swapları sadece alım-satım amacıyla da kullanılabilir. CDS sözleșmesinde kredi risk koruma alıcısı, söz konusu riski üstlenmek zorunda değildir. Taraflar farklı varlık sınıflarının olası yanlıș fiyatlandırılmasında ya da pazarın belli bir yöne doğru hareket edeceğine inanarak ve açık pozisyon almak amacıyla CDS piyasasına girebilirler. CDS'lerin genellikle, alım-satım amacıyla kullanımları, CDS piyasasını daha likit hale getirmektedir.

CDS'ler banka bilançolarından referans varlık için ayrılan kredi karșılığının ya da sermaye yükümlülüğünün daha düșük bir oranla hesaplanabilmesini sağlamıș olduğu güvence ile mümkün kılmaktadır. Bu durum banka için kaynak maliyetini düșürmek suretiyle hem avantaj yaratmakta hem de CDS'e konu olan kredi olaylarının gerçekleșmesi halinde sadece bankanın tüm riskini karșılayabilecek kadar fon giriși sağlayamama durumu ve genelde de piyasadaki olumsuzlukların geçici olușu, bankanın kriz dönemlerinde sermaye sıkıntısı içine girmesini engellemektedir (Turguttopbaș, 2013, s. 40).

Dünya piyasalarının ABD kökenli bağımsızlığına ilișkin șüphe duyulan derecelendirme kurulușları tarafından değerlendirilmesi ve 2008 yılında $A B D$ 'de patlak veren konut edimine yönelik kullandırılan kredilerde yapıldığı gibi yanlıș değerlendirmelerin yasal yaptırımlara maruz kalmaması CDS'lere olan ihtiyacı arttırmıștır.

CDS primleri serbest piyasa șartları altında oluștuğu için ülkelerin kredi riskinin değerlendirilmesinde kredi derecelendirme kurulușlarına göre daha bağımsız ve güvenilir araçlar olarak kullanılmaktadır. Ayrıca CDS primleri, rakamlarla ifade edildiği için kredi derecelendirme kurulușları tarafından harf cinsinden açıklanan notlara göre ülkelerin arasında daha doğru bir șekilde değerlendirme yapılmasına olanak vermektedir.

Bu çalıșmada, 2010-2018 yılları arasında yer alan üçer aylık veriler kullanılarak Türkiye'ye ilișkin CDS primleri ile portföy yatırımları arasındaki ilișki zaman serisi analizi ile test edilmiștir. Bu amaç doğrultusunda literatürde yer alan çalıșmalar özetlendikten sonra analizde kullanılan veri seti, yöntemler ile analiz sonuçları açıklanmıștır. 


\section{Literatür}

Kredi temerrüt swapları ile ilgili çalıșmalar ilk Duffie (1999) tarafından bașlatılmıștır. Literatür incelendiğinde, kredi temerrüt swapları ile ilgili çalıșmaların genellikle 2008 Küresel Finans Krizi sonrası kredi derecelendirme kurulușlarının açıkladığı kredi notlarının kredi riskini yansıtma da yeterli olmadığı görüșü hakim olmaya bașladıktan sonra hızlandığı görülmektedir. Yine de Türkiye'de CDS dağılımları üzerine yapılmıș çok fazla sayıda çalıșma yoktur. Türkiye'nin CDS priminin seyrine ilișkin yapılan çalıșmalar așağıda sunulmuștur:

\begin{tabular}{|c|c|c|c|}
\hline YAZARLAR & ÇALIȘMA & YÖNTEM & SONUC̣ \\
\hline $\begin{array}{l}\text { Kunt ve Tas, } \\
\text { (2008) }\end{array}$ & $\begin{array}{l}\text { Kredi Temerrüt Swap- } \\
\text { ları ve Türkiye'nin CDS } \\
\text { Priminin Tahmin Edil- } \\
\text { mesine Yönelik Bir Uy- } \\
\text { gulama }\end{array}$ & $\begin{array}{l}\text { 2000: 10-2008: } 1 \text { dö- } \\
\text { nemine ilișkin EKK Tah- } \\
\text { mini }\end{array}$ & $\begin{array}{l}\text { Opsiyon fiyatlamasında etkili } \\
\text { olan beș temel değișkenden } \\
\text { risksiz faiz oranı, referans var- } \\
\text { lığın getirisi ve referans varlığın } \\
\text { getirisinin volatilitesi ile CDS } \\
\text { primleri arasında uzun dönemli } \\
\text { bir ilișkinin mevcut olduğu sonu- } \\
\text { cuna ulașılmıștır. }\end{array}$ \\
\hline $\begin{array}{l}\text { Kilıç } \\
(2009)\end{array}$ & $\begin{array}{l}\text { Kredi Temerrüt Swap } \\
\text { Primini Etkileyen Fak- } \\
\text { törler ve Türkiye Üzeri- } \\
\text { ne Uygulamalar }\end{array}$ & $\begin{array}{l}\text { 2005: 1-2008:8 döne- } \\
\text { mine ait günlük veriler } \\
\text { kullanılarak kısa dö- } \\
\text { nemde regresyon yön- } \\
\text { temi, aylık veriler kulla- } \\
\text { nılarak uzun dönemde } \\
\text { Johansen Eșbütünleșme } \\
\text { Testi }\end{array}$ & $\begin{array}{l}\text { Türkiye'nin ülke kredi temerrüt } \\
\text { swap primi ile ekonomik yapı- } \\
\text { sının değișkenliği, temerrüde } \\
\text { uzaklığı ile yayılma etkisi ara- } \\
\text { sında pozitif bir ilișki tespit edi- } \\
\text { miștir. }\end{array}$ \\
\hline $\begin{array}{l}\text { Ersan ve } \\
\text { Günay } \\
\text { (2009) }\end{array}$ & $\begin{array}{l}\text { Kredi Risk Gösterge- } \\
\text { si Olarak Kredi Risk } \\
\text { Swapları (CDS) ve Ka- } \\
\text { patma Davasının Türki- } \\
\text { ye Riski Üzerine Etkisi- } \\
\text { ne Dair Bir Uygulama }\end{array}$ & VAR Yöntemi & $\begin{array}{l}\text { Kapatma davasının Türkiye } \\
\text { kredi temerrüt swap spreadleri } \\
\text { üzerinde anlamlı bir etkisi yok- } \\
\text { tur. Türkiye kredi temerrüt swap } \\
\text { spreadleri üzerinde etkili olan } \\
\text { değișkenler, Türkiye'ye ilișkin } \\
\text { yurtiçi değișkenlerden ziyade } \\
\text { yurtdıșında ișlem gören Euro- } \\
\text { bond getirileri ve Dow Jones } \\
\text { Endeksi getirisi değișkenleridir. }\end{array}$ \\
\hline \begin{tabular}{|l|} 
Köseoğlu \\
$(2013)$
\end{tabular} & $\begin{array}{l}\text { The Transmission of } \\
\text { Volatility Between the } \\
\text { CDS Spreads and Equ- } \\
\text { ity Returns Before, Du- } \\
\text { ring and After the Glo- } \\
\text { bal Financial Cirisis: } \\
\text { Evidence from Turkey }\end{array}$ & $\begin{array}{l}\text { 2005:1-2012:6 döne- } \\
\text { mine ilișkin VAR Ana- } \\
\text { lizi ve BEKK-GARCH } \\
\text { Modeli }\end{array}$ & $\begin{array}{l}\text { CDS dağılımı ile hisse senedi } \\
\text { getirileri arasında negatif bir } \\
\text { ilișki olduğu tespit edilmiștir. }\end{array}$ \\
\hline
\end{tabular}




\begin{tabular}{|c|c|c|c|}
\hline \begin{tabular}{|l} 
Kargı \\
$(2014)$
\end{tabular} & $\begin{array}{l}\text { Credit Default Swap } \\
\text { (CDS) Spreads: The } \\
\text { Analysis of Time Seri- } \\
\text { es For The Interaction } \\
\text { With The Interest Rates } \\
\text { And The Growth In Tur- } \\
\text { kish Economy }\end{array}$ & $\begin{array}{l}2005-2013 \text { dönemine } \\
\text { ilișkin Eșbütünleșme ve } \\
\text { Granger Nedensellik } \\
\text { Testleri }\end{array}$ & $\begin{array}{l}\text { Faiz oranlarının CDS dağılım- } \\
\text { larını etkileyen önemli bir unsur } \\
\text { olduğu gözlemlenmiștir. }\end{array}$ \\
\hline \begin{tabular}{|l|} 
Hancl \\
$(2014)$
\end{tabular} & $\begin{array}{l}\text { Kredi Temerrüt Takasla- } \\
\text { rı ve Bist-100 Arasında- } \\
\text { ki İlișkinin İncelenmesi }\end{array}$ & $\begin{array}{l}\text { Ocak 2008-Aralık } \\
2012 \text { dönemine ilișkin } \\
\text { GARCH Yöntemi }\end{array}$ & $\begin{array}{l}\text { CDS baz puanı ile BIST-100 ge- } \\
\text { tirileri arasında negatif yönlü bir } \\
\text { ilișki bulunmuștur. }\end{array}$ \\
\hline $\begin{array}{l}\text { Șit, Karaca } \\
\text { ve Ekși } \\
(2014)\end{array}$ & $\begin{array}{l}\text { Politik Riskler ve Kredi } \\
\text { Temerrüt Swapları Bor- } \\
\text { sa Endeksini Etkiliyor } \\
\text { mu? Türkiye Örneği }\end{array}$ & $\begin{array}{l}\text { 2005-2014 dönemine } \\
\text { ait VAR Analizi }\end{array}$ & $\begin{array}{l}\text { Türkiye'de CDS primlerinin ve } \\
\text { politik risklerin borsa üzerinde } \\
\text { etkili olmadığı saptanmıștır. }\end{array}$ \\
\hline $\begin{array}{l}\text { Bozkurt } \\
(2015)\end{array}$ & $\begin{array}{l}\text { Finansal İstikrar ile } \\
\text { CDS Primleri Arasın- } \\
\text { daki ilișkinin Bulanık } \\
\text { Regresyon Analizi ile } \\
\text { Tespiti: Türkiye Örneği }\end{array}$ & $\begin{array}{l}\text { 2002:12-2014:06 dö- } \\
\text { nemine ilișkin Bulanık } \\
\text { Regresyon Analizi }\end{array}$ & $\begin{array}{l}\text { Finansal istikrar göstergeleri ile } \\
\text { CDS primleri arasında negatif } \\
\text { bir ilișki olduğu tespit edilmiștir. }\end{array}$ \\
\hline $\begin{array}{l}\text { Kaya vd. } \\
\text { (2015) }\end{array}$ & $\begin{array}{l}\text { Türkiye'nin Derecelen- } \\
\text { dirme Notları ve Kredi } \\
\text { Temerrüt Swap Primle- } \\
\text { rinin Ekonomik ve Sos- } \\
\text { yal Olaylara Tepkisinin } \\
\text { Analizi }\end{array}$ & $\begin{array}{l}\text { 2007:0 1-2014:04 } \\
\text { dönemine ait günlük } \\
\text { verilerle çoklu doğrusal } \\
\text { regresyon yöntemi }\end{array}$ & $\begin{array}{l}\text { Derecelendirme notları ve CDS } \\
\text { primlerinin aynı olaylara her } \\
\text { zaman aynı tepkiyi vermediği } \\
\text { tespit edilmiștir. }\end{array}$ \\
\hline $\begin{array}{l}\text { Akkaya } \\
(2016)\end{array}$ & $\begin{array}{l}\text { Türk Tahvillerinin CDS } \\
\text { Primlerini Etkileyen İç- } \\
\text { sel Faktörlerin Analizi }\end{array}$ & $\begin{array}{l}\text { 2008:01-2016:03 dö- } \\
\text { nemine ait VAR Analizi }\end{array}$ & $\begin{array}{l}\text { ABD dolar kurundaki ve EMBI + } \\
\text { Türkiye endeksindeki aylık de- } \\
\text { ğisșimlerin, Türkiye } 5 \text { yıl vadeli } \\
\text { ABD Tahvil CDS priminin aylık } \\
\text { değișimleri üzerinde etkili oldu- } \\
\text { ğu tespit edilmiștir. }\end{array}$ \\
\hline $\begin{array}{l}\text { Telek ve Șit } \\
(2016)\end{array}$ & $\begin{array}{l}\text { Türkiye'de Takipteki } \\
\text { Kredilerin ve Risk Primi } \\
\text { Arasındaki İlișkinin İn- } \\
\text { celenmesi }\end{array}$ & $\begin{array}{l}\text { 2005:1-2015:3 döne- } \\
\text { mine ait VAR, Etki-Tep- } \\
\text { ki Analizi ve Granger } \\
\text { Nedensellik Testleri }\end{array}$ & $\begin{array}{l}\text { CDS primlerinin takipteki kre- } \\
\text { diler üstünde nedensellik ilișkisi } \\
\text { tespit edilmiștir. }\end{array}$ \\
\hline $\begin{array}{l}\text { Varlık ve } \\
\text { Varlık } \\
\text { (2017) }\end{array}$ & $\begin{array}{l}\text { Türkiye'nin CDS Primi- } \\
\text { nin Oynaklığı }\end{array}$ & $\begin{array}{l}\text { 2008:1-2016:10 dö- } \\
\text { nemini kapsayan gün- } \\
\text { lük verilerle GARCH-M } \\
\text { Modeli }\end{array}$ & $\begin{array}{l}\text { CDS'lerin oynaklığında meyda- } \\
\text { na gelen artıșı CDS'lerin orta- } \\
\text { lama getirilerini etkilediği sonu- } \\
\text { cuna ulașmıșlardır. }\end{array}$ \\
\hline $\begin{array}{l}\text { Danacl, Șit } \\
\text { ve Șit } \\
(2017)\end{array}$ & $\begin{array}{l}\text { Kredi Temerrüt Swapla- } \\
\text { rının (CDS'lerin) Büyü- } \\
\text { me Oranıyla İlișkilendi- } \\
\text { rilmesi: Türkiye Örneği }\end{array}$ & $\begin{array}{l}\text { 2009-2015 dönemine } \\
\text { ait Toda-Yamamoto } \\
\text { Nedensellik Testi }\end{array}$ & $\begin{array}{l}\text { Ekonomik büyümeyle CDS de- } \\
\text { ğișkenleri arasında çift yönlü } \\
\text { nedensellik ilișkisi saptanmıștır. }\end{array}$ \\
\hline \begin{tabular}{|l} 
Atasever \\
(2017)
\end{tabular} & $\begin{array}{l}\text { Türkiye'de Risk Primi } \\
\text { (CDS), Piyasa Göster- } \\
\text { geleri ve Seçim Dönem- } \\
\text { lerine İlișkin Ekonomet- } \\
\text { rik Analiz }\end{array}$ & $\begin{array}{l}\text { 2010:6-2016:12 dö- } \\
\text { nemine ilișkin VAR } \\
\text { Analizi ve Johansen } \\
\text { Eșbütünleșme Testi }\end{array}$ & $\begin{array}{l}\text { Türkiye'nin CDS priminin BIST } \\
\text { kapanıș fiyatlarını ve Merkez } \\
\text { Bankası rezervlerini düșük dü- } \\
\text { zeyde etkilediği sonucuna ulașı- } \\
\text { mıștır. Ayrıca dolar kurunun ve } \\
\text { tahvil faiz oranının CDS primini } \\
\text { düșük düzeyde etkilediği sonu- } \\
\text { cuna ulașılmıștır. }\end{array}$ \\
\hline
\end{tabular}




\begin{tabular}{|c|c|c|c|}
\hline $\begin{array}{l}\text { KIlcl } \\
(2017)\end{array}$ & $\begin{array}{l}\text { CDS Primleri ile Bir } \\
\text { Ülkenin Ekonomik ve } \\
\text { Finansal Değișkenleri } \\
\text { Arasındaki Nedensellik } \\
\text { illișkisinin Değerlendiril- } \\
\text { mesi: Türkiye Örneği }\end{array}$ & $\begin{array}{l}\text { 2010-2016 dönemine } \\
\text { ilișkin Engle-Granger } \\
\text { Testi ve Johansen Kuen- } \\
\text { tegrasyon Testi }\end{array}$ & $\begin{array}{l}\text { CDS primi ile büyüme, cari açık, } \\
\text { ișsizlik ve enflasyon arasında } \\
\text { zayıf ilișkinin olduğu tespit edil- } \\
\text { miștir. }\end{array}$ \\
\hline $\begin{array}{l}\text { Münyas } \\
\text { (2018) }\end{array}$ & $\begin{array}{ll}\text { CDS Primi ve } & \text { Piyasa } \\
\text { Göstergeleri } & \text { Arasın- } \\
\text { daki Ilișkinin } & \text { Değer- } \\
\text { lendirilmesi } & \text { Üzerine } \\
\text { Ekonometrik Bir Analiz: } & \text { Aürkiye Örneği }\end{array}$ & $\begin{array}{l}2007-2017 \text { dönemini } \\
\text { içeren yıllık verilerle } \\
\text { regresyon modelleri }\end{array}$ & $\begin{array}{l}\text { CDS primi ile BIST } 100 \text { Endeksi } \\
\text { arasında ters; dolar kuru ve gös- } \\
\text { terge tahvil faiz oranı arasında } \\
\text { doğrusal bir ilișki tespit edilmiș- } \\
\text { tir. }\end{array}$ \\
\hline $\begin{array}{l}\text { Kilcl } \\
(2019)\end{array}$ & $\begin{array}{l}\text { Dıș Borçların Ülke CDS } \\
\text { Primleri Üzerindeki Etki- } \\
\text { sinin incelenmesi: Türki- } \\
\text { ye Örneği }\end{array}$ & $\begin{array}{l}\text { 2000:Ç 1-2018:Ç2 } \\
\text { dönemi için çeyreklik } \\
\text { veriler kullanılarak Fou- } \\
\text { rier SHIN Eșbütünleșme } \\
\text { Testi ve Fourier Gran- } \\
\text { ger Nedensellik Testi }\end{array}$ & $\begin{array}{l}\text { Dıș borç/GSYiH oranının } 5 \text { yıllık } \\
\text { CDS primleri üzerinde kısa dö- } \\
\text { nemde bir etkisi olmadığı fakat } \\
\text { uzun dönemde etkili olduğu so- } \\
\text { nucuna varılmıștır. }\end{array}$ \\
\hline
\end{tabular}

\section{Uygulama}

\subsection{Veri Seti, Yöntem ve Bulgular}

Çalıșmanın uygulama kısmında portföy yatırımları ile CDS primleri arasındaki ilișki 2010-2018 yılları arasında yer alan üçer aylık veriler kullanılarak zaman serisi analizi ile test edilmiștir. Portföy yatırımlarına ilișkin bilgiler Türkiye Cumhuriyet Merkez Bankası Elektronik Veri Dağıtım Sistemi'nden (EVDS) elde edilmiștir. CDS primlerine ait veriler ise investing veri tabanından elde edilmiștir. Portföy yatırımlarının CDS primleri üzerindeki etkisini belirlemek için ilk olarak zaman etkeni dikkate alınmıștır. Analize konu edilen veri seti zaman serisi niteliğinde olduğundan, ilk olarak veri setinin birim kök içerip içermediğine bakılmıștır.

\subsubsection{Birim Kök Testi}

Verilerin zaman serisine dayandığı çalıșmalarda öncelikle serilerin durağan olup olmadıklarına bakılmalıdır. Analizde kullanılan değișkenler arasında anlamlı ilișkiler olabilmesi için, serilerin durağan olması ve aynı düzeyden homojen olması gereklidir (Korkmaz ve Uygurtürk, 2008 , s. 125).

Durağan olmayan serilerle çalıșıldığında, regresyon sonuçları gerçekçi olamayacak ve sahte regresyona neden olacaktır (Enders, 2004, s. 171). Durağan bir seri birim kök içermemektedir. Böyle bir serinin ortalaması, varyansı ve kovaryansı zaman içerisinde değișmez (Gujarati, 1999 , s. 713). 
Bir serinin birim köke sahip olup olmamasına göre serinin durağan olup olmadığı söylenebilir. Bununla birlikte serinin birim kök içermemesi, zamana göre farklılașmayan bir varyansa sahip olması, meydana gelebilecek șokların zamanla yok olabileceği anlamına gelmektedir. Eğer seriler durağan değil ise rassal șoklardan etkilenebilirler (Libanio, 2005, s. 146).

Çalıșmada kullanılan serilerin durağan olup olmadıklarının tespit edilmesi için Augmented Dickey Fuller (ADF) ve Kwiatkowski - Philips - Schmidt - Shin (KPSS) birim kök testleri uygulanmıștır. ADF birim kök testi için formül düzeni așağıdaki gibidir:

$$
\begin{aligned}
& \Delta y_{t}=\alpha+\beta T+\varphi y_{t-1}+\sum_{i=1}^{k} \delta_{i} \Delta y_{t-1}+u_{t} \\
& \Delta y_{t}=\alpha+\varphi y_{t-1}+\sum_{i=1}^{k} \delta_{i} \Delta y_{t-1}+u_{t}
\end{aligned}
$$

Formüllerdeki $y_{+}$değișkeni birim kökün varlığını test etmektedir. Illk denklemdeki T, deterministik trendi ifade etmektedir. Modele ayrıca gecikmeli fark terimleri ilave edilmesi ile hata teriminin otokorelasyonsuz olması durumu da ortadan kaldırılmıștır. Illk formülde $y_{t}$ değișkeni, trend yapıya sahip durağan olduğu alternatifine karșı birim köke sahip temel hipotezi analiz etmektedir. İkinci denklem ise $y_{t}$ değișkenin, ortalama etrafında durağan olmasına karșı birim kökü olduğu temel hipotezi test etmektedir. Bu varsayımların alında kullanılacak hipotezler șu șekildedir:

Birim kök vardır/Seri durağan değildir $\left(H_{0}: \varphi=0\right)$

Birim kök yoktur/Seri durağandır $\left(H_{1}: \varphi=0\right)$

$\varphi$ değerinin sıfırdan farklı olmaması durumunda, birim kök temel hipotezi reddedilememektedir. $\varphi<0$ olması durumunda ise, alternatif hipotez kabul edilecektir.

Tablo 1. ADF ve KPSS Birim Kök Testleri Sonuçları

\begin{tabular}{|l|c|c|c|c|}
\hline & \multicolumn{2}{|c|}{ ADF } & \multicolumn{2}{c|}{ KPSS * } \\
\hline Değișkenler & Düzey & 1. Fark & Düzey & 1.Fark \\
\hline CDS & $\begin{array}{r}2,2468 \\
(1,000)\end{array}$ & $\begin{array}{r}-13,0387 \\
(0,000)\end{array}$ & 0,128 & 0,289 \\
\hline PY & $\begin{array}{r}-2,1293 \\
(0,512)\end{array}$ & $\begin{array}{r}-7,1866 \\
(0,000)\end{array}$ & 0,115 & 0,582 \\
\hline
\end{tabular}

*ADF testi trend sabitli model için kritik değerler; \%1 $(-4,356), \% 5(-3,595)$ ve \%10 $(-3,233)$

*KPSS testi trend sabitli model için kritik değerler; \%1 $(0,216), \% 5(0,146)$ ve \%10 $(0,119)$

ADF ve KPSS birim kök testi sonuçlarına göre, serilerin seviyelerinde birim kök tașıdığı belirlenmiștir. Bu sonuçlarla serilerin durağanlığa 
sahip olmadığı görülmektedir. Serilerin düzey değerlerinde durağan olmadıkları tespit edildiği için birinci derece farkları alınarak tekrar analize tabi tutulmușlardır. Sonuç olarak serilerin hem ADF hem de KPSS birim kök testi sonucunda birinci dereceden bütünleșik olduğu sonucuna varılmıștır. Serilerin seviyesinde yapılan ADF testi sonucunda elde edilen test istatistiklerinin \%5 kritik değerinden küçük olması nedeniyle birim kök tașıdıkları, serilerin birinci farkı alındığında test istatistiklerinin \%5 kritik değerinden büyük olması nedeni ile birim kök tașımadıkları yani durağan oldukları belirlenmiștir. KPSS testi sonucunda elde edilen test istatistiklerinin düzey değerlerinin kritik değerlerden küçük olduğu için serilerin durağan olmadığı belirlenmiștir. Serilerin birinci farkı alındığında elde edilen test istatistiklerinin kritik değerlerden büyük olduğu için serilerin durağan hale geldiği sonucuna varılmıștır.

Yapılan ADF ve KPSS birim kök testleri sonucunda serilerin birinci farklarında durağan çıkmaları, seriler arasında Johansen eșbütünleșme yani uzun dönemli ilișkinin olup olmadığının test edilmesini gerekli kılmıștır.

\subsubsection{Johansen Eșbütünleșme Testi}

Eșbütünleșme analizi sayesinde serileri durağan duruma dönüștürmek için fark alma gerekmeyecek ve uzun dönemli bilgi kaybı olmayacaktır. Eșbütünleșme testi düzeyde durağan olmayan serilerin uzun dönemde birlikte hareket edip etmediklerini ortaya koymaktadır. Johansen eșbütünleșme testi, ele alınan tüm serilerin özgün düzeylerinde durağan olmamasını ve aynı derecede farkı alındığında durağan duruma gelmelerini gerektirmektedir (Kılıç, 2009, s. 208).

Eșbütünleșme testi sonucundan elde edilen sonuçlar Tablo 2'de verilmiștir. Eșbütünleșme ilișkisi olmadığı yönünde kurulan hipotezine karșı, hipotez alternatifi eșbütünleșme ilișkisi olduğu șeklinde kurulmaktadır.

Tablo 2. Johansen Eșbütünleșme Testi

\begin{tabular}{|l|c|c|c|c|}
\hline Hipotez & Özdeğer & İz İstatistikleri & Kritik Değer (\%5) & Olasılık \\
\hline $\mathrm{H}_{0}: \mathrm{r}=0$ & 0,346 & 16,872 & 15,494 & 0,0308 \\
\hline $\mathrm{H}_{0}: \mathrm{r} \leq 1$ & 0,083 & 3,841 & 3,384 & 0,0903 \\
\hline
\end{tabular}

Eșbütünleșme testi sonuçları incelendiğinde, iz istatistiği değerlerinin kritik değerden büyük olması sebebiyle en az bir tane eșbütünleșme ilișkisi olduğu, yani serilerin aralarında uzun dönemli bir dengenin oldu- 
ğu belirlenmiștir. Bu sonuçlara göre, portföy yatırımları ile CDS primleri arasında uzun dönemli bir ilișki olduğu belirlenmiștir.

\section{Tablo 3. Eșbütünleșme Eșitliği}

\begin{tabular}{|l|c|c|c|c|}
\hline & Katsayı & Standart Hata & Katsayı & Standart Hata \\
\hline CDS & 1,000 & & 1,000 & \multirow{2}{*}{4,0905} \\
\hline C & 0,0054 & \multirow{2}{*}{3,8805} & 0,0773 & \\
\cline { 1 - 2 } PY & $-3,4506$ & & $-4,6405$ & \\
\hline
\end{tabular}

Eșbütünleșme analizi sonucunda değișkenler arasındaki uzun dönemli bir ilișki olduğu belirlendikten sonra bu değișkenlerin uzun dönem katsayılarının tahmini yapılmıștır. Eğer seriler birinci farkta durağan ve aynı zamanda değișkenler arasında eșbütünleșme var ise sıradan en küçük kareler yönteminin kullanılması sapmalı sonuçlar verecektir. Bu nedenle "Tam Düzeltilmiș En Küçük Kareler Yöntemi (FMOLS)" kullanılmıștır. Bir diğer yöntem olan "Dinamik En Küçük Kareler Yöntemi (DOLS)", hata terimi ile bağımsız değișken arasındaki içsellik ilișkisini göz önünde bulundurulması ile birlikte otokorelasyon sorununu da göz önünde bulundurmaktadır.

Elde edilen sonuçlara göre, portföy yatırımları ile CDS primleri arasında negatif yönlü bir ilișki olduğu belirlenmiștir. FMOLS tahmincisine göre porfföy yatırımlarında meydana gelebilecek bir birimlik artıșın, CDS primlerinde -\%3,45'lik bir azalıșa neden olduğu, DOLS tahmincisine göre ise portföy yatırımlarında meydana gelen bir birimlik artıșın, CDS primlerinde $-\% 4,64^{\prime}$ lük bir azalıșa neden olduğu sonucuna varılmıștır.

\subsubsection{Granger Nedensellik Testi}

Değișkenler arasındaki uzun dönemli bir ilișkinin olup olmadığını test etmek amacıyla yapılan eșbütünleșme testi sonrasında kısa dönem ilișkinin olup olmadığı Granger Nedensellik Testi ile sınanmıștır. Eșbütünleșme testi için kurulan VAR (Vektör Otoregresif Model) modelinde optimal gecikme uzunluğunun 2 olduğu belirlenmiștir. VAR modeli birbiriyle karșılıklı ilișki içerisinde bulundukları düșünülen değișkenlerin etkileșimlerini ortaya koymak için kullanılan denklem sistemidir. Kurulan VAR denkleminde kullanılan değișkenlerin karșılıklı etkileșim içinde olup olmadıklarını tespit etmek için de Granger nedensellik testi uygulanmıștır (Conkar ve Vergili, 2017, s. 64). Bu sebeple Granger nedensellik testi için gecikme uzunluğu 2 kabul edilmiștir. 
Tablo 4. Granger Nedensellik Testi Sonuçları

\begin{tabular}{|l|c|c|}
\hline & F-istatistik & Olasilık \\
\hline DCDS $\rightarrow$ DPY & 0,0175 & 0,8955 \\
\hline DPY $\rightarrow$ DCDS & 7,4099 & 0,0105 \\
\hline
\end{tabular}

Granger nedensellik testi sonuçları Tablo 4 'de verilmiștir. Portföy yatırımlarının CDS primleri üzerinde kısa dönemde bir etkisinin olduğu F-istatistiği anlamlılık düzeyinin \%5 anlamlılık düzeyinden yüksek olduğu ancak CDS primlerinin portföy yatırımları üzerinde bir etkisinin olmadığı tespit edilmiștir. Portföy yatırımlarının CDS primlerinin nedeni olduğu belirlenmiștir.

\subsubsection{Etki Tepki Analizi}

Serilerin birinci farklarında durağan oldukları tespit edildikten sonra diğer analizlerin yapılabilmesi için uygun gecikme uzunluğunun belirlenmesi gereklidir. Optimal gecikme sayısının belirlenebilmesi için, AIC (Akaike Information Criterion), SC (Schwarz Information Criterion) ve $\mathrm{HQ}$ (Hannan-Quinn Information Criterion) bilgi kriterlerinden yararlanılmıștır. En düșük değere sahip olan bilgi kriterine karșılık gelen gecikme uzunluğu modelin gecikme uzunluğu olarak ele alınır.

Tablo 5. Gecikme Uzunluğu

\begin{tabular}{|c|c|c|c|c|c|c|}
\hline Lag & LogL & LR & FPE & AIC & SC & HQ \\
\hline & & & & & & \\
\hline $\mathbf{0}$ & -191.9476 & NA & 931.7284 & 12.51275 & 12.60527 & 12.54291 \\
\hline $\mathbf{1}$ & -173.5443 & $33.24476^{*}$ & $368.3242^{*}$ & $11.58350^{*}$ & $11.86105^{*}$ & $11.67398^{*}$ \\
\hline $\mathbf{2}$ & -172.0538 & 2.500211 & 434.9949 & 11.74540 & 12.20798 & 11.89619 \\
\hline $\mathbf{3}$ & -171.2629 & 1.224574 & 540.5192 & 11.95245 & 12.60005 & 12.16355 \\
\hline $\mathbf{4}$ & -170.1581 & 1.568087 & 663.7216 & 12.13923 & 12.97187 & 12.41065 \\
\hline
\end{tabular}

Değișkenler yıllık verilerden meydana geldiği için maksimum 4 gecikme ile kurulan VAR modelinde gecikme uzunluğunun 1 olduğu belirlenmiștir. Bu sonuçlara göre Akaike Bilgi Kriteri diğer modellere göre daha düșük değer aldığı için Akaike Bilgi Kriteri seçilmiș ve gecikme değeri VAR (3) modeli olarak belirlenmiștir.

Etki tepki fonksiyonlarında portföy yatırımlarındaki bir birimlik șokun araștırmaya konu CDS primleri değișkeni üzerindeki etkisi değerlendirilmektedir. Portföy yatırımlarındaki bir birimlik șokun CDS primi değișkeni üzerinde ne derece etki ettiği etki tepki fonksiyonlarına bağlı olarak elde edilen grafiklerde açıklanmıștır. 


\section{Grafik 1}

CDS Değişkenindeki Bir Birimlik Şokun

PY Değişkeni Üzerindeki Etkisi

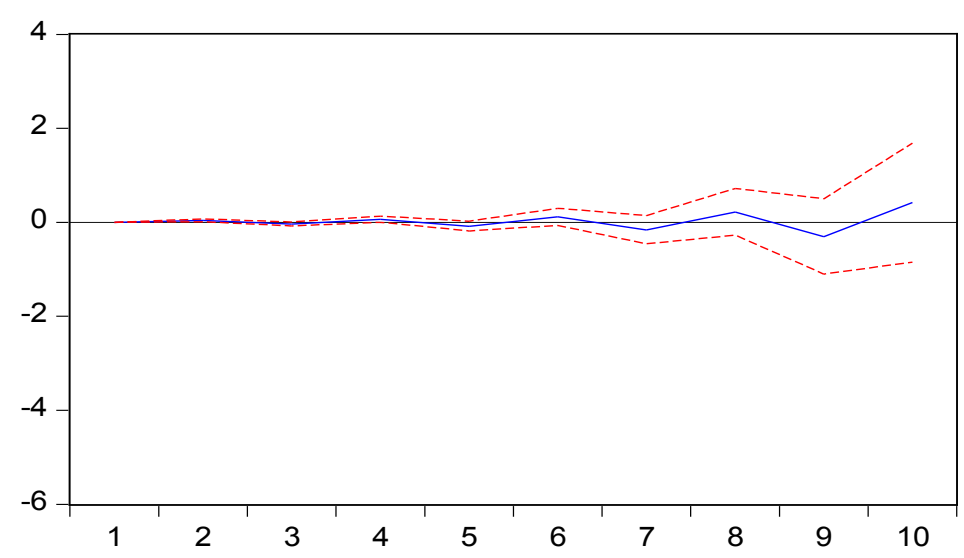

Grafik 1'de CDS primlerindeki bir birimlik șokun portföy yatırımları değișkeni üzerindeki ne derece etki ettiği verilmiștir. Grafik 1'de görüldüğü üzere CDS primlerindeki bir birimlik șok etki bașlangıçta pozitif etkide bulunurken, altı çeyrek dönem sonra bu etkinin dalgalanma gösterdiği görülmektedir.

\section{Grafik 2}

PY Değişkenindeki Bir Birimlik Şokun

CDS Değişkeni Üzerindeki Etkisi

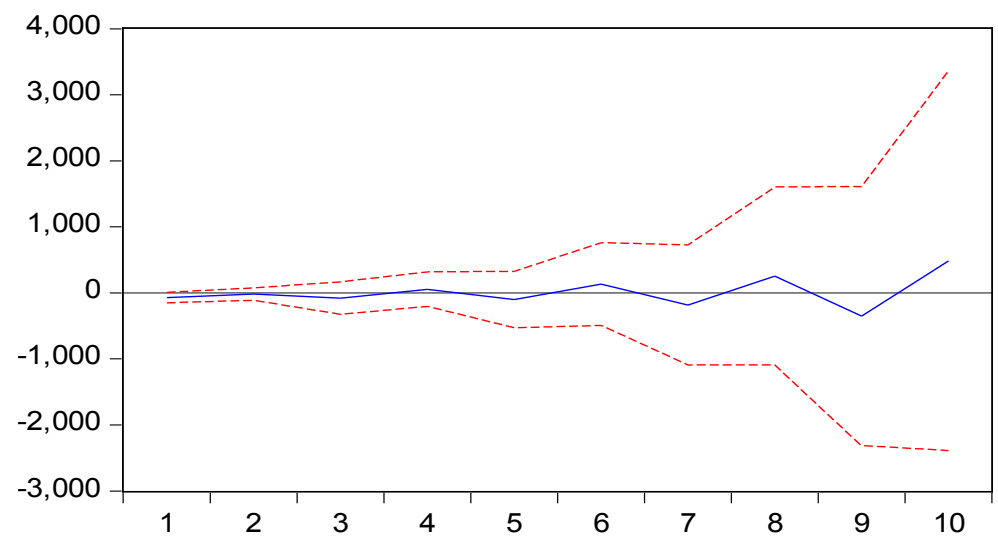


Grafik 2'de portföy yatırımlarındaki bir birimlik șokun CDS primleri değișkeni üzerindeki ne derece etki ettiği verilmiștir. Grafik 2 'de görüldüğ̈̈ üzere portföy yatıımlarında bir birimlik șok etki bașlangıçta negatif etkide bulunurken, altı çeyrek dönem sonra bu etkinin pozitife döndüğü, genel olarak ise dalgalanma gösterdiği görülmektedir.

\section{Sonuç}

Kısa sürede paraya çevrilebildiğinden porfföy yatırımlarının, yatırımcılar açısından diğer yatııım türlerine göre daha risksiz olduğu düșünülmektedir. Fakat aynı zamanda ülkede yașanan en ufak bir kriz durumunda kısa sürede likiditeye çevrilebilme özelliği nedeniyle, ülkeyi en kolay terk edebilen yatırım türü olduğu için riskli olduğu düșünülmektedir.

Bir ülkenin risk düzeyi arttıkça, o ülkeye yapılan yatııım giriși azalmaktadır. Dolayısıyla, ülkenin kredi riskinin önemli bir göstergesi olarak kabul gören CDS primleri, yatırımcılar açısından dikkate alınmaktadır. Bu nedenle Türkiye'ye ait 2010-2018 yılları arasında yer alan üçer aylık veriler kullanılarak zaman serisi analiziyle portföy yatırımları ile CDS primleri arasındaki ilișki incelenmiștir. Illk olarak ADF ve KPSS birim kök testleriyle çalıșmada kullanılan serilerin durağan olup olmadıkları tespit edilmeye çalıșılmıștır ve durağan olmadıkları tespit edildiği için serilerin birinci derece farkları alındığında durağan hale geldikleri görülmüștür. Yapılan ADF ve KPSS birim kök testleri sonucunda serilerin birinci farklarında durağan çıkmaları, seriler arasında Johansen eșbütünleșme yani uzun dönemli ilișkinin olup olmadığının test edilmesini gerekli kılmıștır.

Johansen eșbütünleșme testi sonuçlarına göre iz istatistiği değerinin kritik değerden büyük olması sebebiyle en az bir tane eșbütünleșme ilișkisi olduğu, yani porfföy yatıımları ile CDS primleri arasında uzun dönemli bir ilișki olduğu belirlenmiștir.

Serilerin birinci farkta durağan ve değișkenler arasında eșbütünleșme ilișkisi olduğu tespit edildiği için sıradan en küçük kareler yönteminin kullanılması sapmalı sonuçlar verecektir. Bu yüzden FMOLS ve hata terimiyle bağımsız değișken arasındaki ilișkisini ve otokorelasyon sorununu dikkate alan DOLS yöntemi kullanılmıștır. Elde edilen sonuçlara göre portföy yatıımları ile CDS primleri arasında negatif yönlü bir ilișki olduğu belirlenmiștir.

Değișkenler arasındaki uzun dönemli ilișkinin tespit edilmesi sonrasında kısa dönemli bir ilișkinin olup olmadığı da Granger nedensellik 
testi ile sınanmıștır. Granger nedensellik testi sonuçlarına göre portföy yatırımlarının CDS primleri üzerinde kısa dönemde bir etkisinin olduğu, F-istatistiği anlamlılık düzeyinin \%5 anlamlılık düzeyinden yüksek olduğu ancak CDS primlerinin portföy yatırımları üzerinde bir etkisinin olmadığı belirlenmiștir. Daha sonra gecikme uzunluğu belirlenerek VAR analizi yapılmıștır. Değișkenler yıllık verilerden meydana geldiği için maksimum 4 gecikme ile kurulan VAR modelinde gecikme uzunluğunun 1 olduğu tespit edilmiștir. Söz konusu değișkenler arasındaki ilișkinin birbirleri üzerindeki etkilerini belirlemeye yönelik daha doğru bilgilere ulașılmak istenmesi, etki-tepki analizi uygulanmasını gerekli kılmıștır.

Etki-tepki fonksiyonlarında, portföy yatırımlarındaki bir birimlik șokun araștırmaya konu CDS primleri üzerindeki etkisi değerlendirilmektedir. Yapılan etki-tepki analizi sonucunda CDS primlerindeki bir birimlik șokun bașlangıçta portföy yatırımlarını pozitif yönde etkilediği, altı çeyrek dönem sonra ise bu etkinin dalgalanma gösterdiği belirlenmiștir. Portföy yatırımlarında meydana gelen bir birimlik șokun ise CDS primleri değișkeni üzerinde bașlangıçta negatif etkide bulunduğu, altı çeyrek dönem sonra bu etkinin pozitife döndüğü, genel olarak ise dalgalanma gösterdiği belirlenmiștir.

Bu çalıșmada elde edilen bulgulardan hareketle portföy yatırımları ile CDS primlerinin oynaklığı analiz edilmiștir. Bu çalıșmanın CDS primlerindeki değișimlerin belirleyicilerinin tespit edilmesine yönelik ileride yapılacak çalıșmalara kaynak teșkil edeceği düșünülmektedir. İlerleyen dönemlerde yapılacak çalıșmalarda, çalıșma dönemi uzatılarak ve Türkiye dıșındaki diğer gelișmekte olan ülkeler de çalıșmaya dahil edilerek farklı ekonometrik yöntemlerin uygulanacağı daha verimli analizlerin yapılması önerilebilir. Gelișmekte olan ülkeler arasında yapılan bir karșılaștırma, CDS primlerindeki değișimleri etkileyen unsurların analiz edilmesiyle ilgili daha fazla bilginin sağlanmasını mümkün hale getirebilecektir. 


\section{KAYNAKÇA}

Akkaya, M., (2016). Türk Tahvillerinin CDS Primlerini Etkileyen İçsel Faktörlerinin Analizi. Maliye Finans Yazıları, (107), 129-146.

Anson, M.J.P., Fabozzi, F.J., Choudhry, M. \& Chen, R.R. (2004). Credit Derivatives: Instruments, Applications and Pricing (1 st Edition). New Jersey: John Wiley \& Sons Ltd.

Atasever, G. (2017). Türkiye'de Risk Primi (CDS), Piyasa Göstergeleri ve Seçim Dönemlerine İlișkin Ekonometrik Analiz. International Journal of Academic Value Studies (Javstudies), 3, 217-226.

Bozkurt, í. (2015). Finansal İstikrar ile CDS Primleri Arasındaki Illișkinin Bulanık Regresyon Analizi İle Tespiti: Türkiye Örneği. Gümüșhane Üniversitesi, Sosyal Bilimler Elektronik Dergisi, 6(13), 64-80.

Choudhry, M. (2006). The Credit Default Swap Basis. New York: Bloomberg Press.

Conkar, M.K. \& Vergili, G., (2017). Kredi Temerrüt Swapları ile Döviz Kurları Arasındaki Illișki: Türkiye İçin Ampirik Bir Analiz. Ömer Halis Demir Üniversitesi İ̈BF Dergisi, 10(4), 59-66.

Danacı, M.C., Șit, M. \& Șit, A., (2017). Kredi Temerrüt Swaplarının (CDS'lerin) Büyüme Oranıyla Ilișkilendirilmesi: Türkiye Örneği. Aksaray Üniversitesi İktisadi ve İdari Bilimler Fakültesi Dergisi, 9(1), 67-78.

Enders, W. (2004). Applied Ecorometrics Time Series (2nd Edition). New York: John Wiley \& Sons.

Ersan, İ. \& Günay, S. (2009). Kredi Risk Göstergesi Olarak Kredi Risk Swapları (CDSs) ve Kapatma Davasının Türkiye Riski Üzerine Etkisine Dair Bir Uygulama. Bankacılar Dergisi, 71, 3-22.

Görmüș, Ș. \& Aksoylu, E. (2017, 19-22 Mayıs). Ülke Riskinin Göstergesi Olarak Kredi Temerrüt Swaplarını Etkileyen Faktörler: Asimetrik Nedensellik Yöntemi. $2^{\text {nd }}$ International Congress on Political, Economic and Social Studies, Sarajevo, 201-229.

Gujarati, D. N. (1999). Temel Ekonometri (Çev. Ü. Șeneșen \& G.G. Șeneșen) (1.Basım). İstanbul:Literatür Yayınları.

Hancı, G. (2014). Kredi Temerrüt Takasları ve BIST-100 Arasındaki Ilișkinin İncelenmesi. İstanbul Kültür Üniversitesi 1. Üretim Ekonomi Kongresi, İstanbul, Sözlü Bildiri.

KargI, B. (2014). Credit Default Swap (CDS) Spreads: The Analysis of Time Series For The Interaction With The Interest Rates And The Growth In Turkish Economy. Montenegrin Journal of Economics, 10(1), 59-66.

Kaya, B., Kaya, Ö.E. \& Yalçıner, K. (2015). Türkiye'nin Derecelendirme Notları ve Kredi Temerrüt Swap Primlerinin Ekonomik ve Sosyal Olaylara Tepkisinin Analizi. Maliye Finans Yazıları, 103, 85-1 12.

Kılcı, E. (2019). Dıș Borçların Ülke CDS Primleri Üzerindeki Etkisinin İncelenmesi: Türkiye Örneği. Sayıștay Dergisi, 1 12, 75-91. 
Kılcı, N. K. (2017). CDS Primleri ile Bir Ülkenin Ekonomik ve Finansal Değișkenleri Arasındaki Nedensellik Illișkisinin Değerlendirilmesi: Türkiye Örneği. Küresel İktisat ve İșletme Çalıșmaları Dergisi, 6(12), 145-154.

Kılıç, C.. (2009). Kredi Temerrüt Swap Primini Etkileyen Faktörler ve Türkiye Üzerine Uygulamalar, Doktora Tezi, Kocaeli Üniversitesi Sosyal Bilimler Enstitüsü, Kocaeli.

Korkmaz, T. \& Uygurtürk, H. (2008). Türkiye'deki Emeklilik Fonları ile Yatırım Fonlarının Performans Karșılaștırması ve Fon Yöneticilerinin Zamanlama Yetenekleri. Kocaeli Üniversitesi Sosyal Bilimler Enstitüsü Dergisi, 15, 114-147.

Köseoğlu, S. (2013). The Transmission of Volatility Between the CDS Spreads and Equity Returns Before, During and After the Global Financial Crisis: Evidence from Turkey. In Proceedings of 8th Asian Business Research Conference, (1-2), 1-14.

Kunt, A. \& Taș, O. (2008). Kredi Temerrüt Swapları ve Türkiye'nin CDS Priminin Tahmin Edilmesine Yönelik Bir Uygulama. İÜ Dergisi/b, 5(1), 78-89.

Libanio, G. A. (2005). Unit Roots in Macroeconomic Time Series: Theory, Implications and Evidence. Nova Economia, 15(3), 145-176.

Münyas, T. (2018). CDS Primi ve Piyasa Göstergeleri Arasındaki Ilișkinin Değerlendirilmesi Üzerine Ekonometrik Bir Analiz: Türkiye Örneği. Atlas International Refereed Journal On Social Sciences, 4(15), 1689-1696.

Șit, A., Karaca, S.S. \& Ekși, I.H. (2014). Politik Riskler ve Kredi Temerrüt Swapları Borsa Endeksini Etkiliyor Mu? Türkiye Örneği. Pamukkale Üniversitesi 18. Finans Sempozyumu, Denizli, Sözlü Bildiri.

Telek, C. \& Șit, A. (2016). Türkiye'de Takipteki Kredilerin ve Risk Primi Arasındaki İlișkinin İncelenmesi: 2005-2015 Dönemi. Gaziantep Üniversitesi 1. Ulusal Lisansüstü İșletme Öğrencileri Sempozyumu, Gaziantep, Sözlü Bildiri.

Turguttopbaș, N. (2013). Sovereing Credit Risk and Credit Default Swap Spread Reflections. International Review of Economics and Management, 1(1), 122-145.

Varlık, S. \& Varlık, N. (2017). Türkiye'nin CDS Priminin Oynaklığı. Finans, Politik \& Ekonomik Yorumlar, 54(632), 9-17.

Weistroffer, C. (2009). Credit Default Swaps: Heading Toward a More Stable System. Deutsche Bank Research, 1-26. 